\title{
Effect of diluents type and preservation periods on some sheep semen characteristics
}

\author{
Salah M. Alragubi
}

Department of animal production, Faculty of agriculture, Bani Walid, University, Libya Salehalragobi@gemail.com

Received: March 30, 2020

Accepted: May 6, 2020

The present study aimed to evaluate three seminal diluents and three conservation periods ( 0,48 and 96 hours) on quality of Barki rams. The three diluents tests were citrateegg yolk, tris - egg yolk and skim milk - egg yolk. The dilution ratio was 1 diluent:10 semen. Semen was collected from barki rams using artificial vagina ram one time monthly in the morning during September, October and November. Semen samples after dilution with the tested diluents were conserved for 48 and 96 hours, then semen quality was evaluated. The results obtained are summarized as following :

1- tris -egg yolk diluent showed the best sperm movement and the livability of the sperm was better compared to the skim milk diluent.

2- tris + skim milk showed the lowest abnormality percentage compared to citrate.

3- The conservation periods had significant effects where the tris- diluent was the best in semen conservation using cooling compared to citrate.

Keywords: Barki rams, semen quality, diluents , preservation.

\section{INTRODUCTION}

Semen of rams can be diluted and stored to keep its quality in good level and this was achieved through conserving rams semen for some hours or days without any reverse effects on its quality or reducing its efficiency on fertilization (Lopez et $a l^{(1)}$. Kulaksiz et al. ${ }^{(2)}$ showed that the success of artificial insemination in sheep led to the importance of establishing new methods for ram sheep dilution and conserving through cooling or freezing to be used out of breeding season. In this respect Chemineau et $a l^{(3)}$ reported that semen diluted increased the possibility of conserving the ram sperms alive for long period, thus the diluents supply the sperms with energy and nutrients to remain alive. Similarly semen diluents contain compounds that product the sperms from the unfavorable impacts of cooling and freezing. The present study was conducted to evaluate the effects of some diluents on Barki rams during the conservation periods 48 or 96 hours and to test three semen characteristics of barki rams. The possibility of conserving and diluting sheep semen will make sheep keeping and intensive production more economically, it will reduce the number of rams in the farm and increased the capability to distribute the genetic makeup of the superior rams in wide areas of Libya.

\section{Animal and management :}

\section{MATERIALS AND METHODS}

Five Barki rams of about $50 \mathrm{~kg} \pm 1.005 \mathrm{~kg}$ live body weight $(\mathrm{LBW})$ were fed at rate of $2 \%$ of LBW for animals. The wheat straw was fed to animals' ad.li The experimental animals were kept under routine veterinary supervision of feed stuffs as illustrated in Table (1) 
Salah M. Alragubi

Table (1). The chemical composition of feed stuffs (on DM basis).

\begin{tabular}{|l|l|l|l|l|l|l|l|}
\hline $\begin{array}{l}\text { feed } \\
\text { stuffs }\end{array}$ & DM\% & OM\% & CP\% & CF\% & EE\% & ASH\% & MFE\% \\
\hline C.F.M & 100 & 93.50 & 14.00 & 12.90 & 2.45 & 6.50 & 64.15 \\
\hline W.S & 100 & 94.70 & 4.11 & 36.00 & 1.51 & 5.30 & 53.08 \\
\hline
\end{tabular}

C.F.M: concentrate feed mixture W.S: Wheat straw

\section{2-Analytical methods:}

The experimental rams were trained for semen collection for one month using the artificial vagina. Semen collection was performed using the artificial vagina. Semen was collected from the experimented rams once every month from each animal and the collected semen was transfers to the laboratory where samples were kept in a water bath at $37^{\circ} \mathrm{C}$, then the ejaculate was diluted into three equal parts where each part was diluted using the tested diluents as presented in Table (2). The tested diluents were prepared according to the method described by Verberckmoes et al. $(2005)^{(4)}$. After diluting the semen samples, the diluted semen was conserved for 0,48 and 96 hours in a Refrigerator at $5^{\circ} \mathrm{C}$. There after the diluted and conserved semen were evaluated for the percent of individual sperm movement, alive sperms and abnormal sperms and semen $\mathrm{PH}$ according to the method of Chemineau et.al. $(1991)^{(3)}$. Live and dead sperms were detected using Wells-Awa acrosome stain ${ }^{(5)}$ (Wells and Awa, 1970). Semen PH was determined using a digital PH - meter after semen collection directly.

Table (2) diluents used in semen treatment

\begin{tabular}{|l|l|l|l|}
\hline Material & Citrate diluent & Tris diluent & Skim milk diluent \\
\hline Tris $(\mathrm{gm})$ & - & 3.63 & - \\
\hline Glucose $(\mathrm{gm})$ & 0.50 & - & 1 \\
\hline Fructose $(\mathrm{gm})$ & - & 0.50 & 1 \\
\hline Sodium citrate $(\mathrm{gm})$ & 2.37 & - & - \\
\hline Citric acid $(\mathrm{gm})$ & - & 1.99 & - \\
\hline Skim milk (\%) & - & - & 80 \\
\hline Egg yolk ( v/vml) & 15 & 14 & 10 \\
\hline Pinclin( iu/ml) & 1000 & 1000 & 1000 \\
\hline Streptomycin $(\mathrm{gm})$ & 100 & 100 & 100 \\
\hline Distilled water & 100 & 100 & 100 \\
\hline
\end{tabular}

\section{3-Statitical analysis:}

Data obtained was evaluated statistically according to Snedecor and Cochran $(1980)^{(6)}$ and the significance among means experimental groups were tested by Duncans multiple rang test (Duncans, 1995) ${ }^{(7)}$.

\section{RESULTS AND DISCUSSION}

It was obvious from data in Table (3) and Figures $(1 \& 2)$ that there were highly significant differences $(\mathrm{P} \leq 0.01)$ for diluents on individual sperm mortality $(\%)$ and a live sperms $(\%)$ for tris and skim milk diluents. These results agreed with the findings of many workers $^{(\mathbf{8 , 9})}$, also the preservation period had a significant effect on diluted and cooling individual motility $\%$ and live sperm $\%$, however the tris- diluents was superior dilution for preserving Barki semen at $5^{\circ} \mathrm{C}$ for 96 hours. This results were in accordance with those obtained by Blackshow ${ }^{(10)}$, Deka and $\mathrm{Rao}^{(11,12)}$ and Yaniz et al. ${ }^{(13)}$. 
Effect of diluents type and preservation periods on some sheep semen characteristics

Table (3). Effect of diluents types and preservation periods on individual motility and live sperms.

\begin{tabular}{|l|l|l|l|l|l|l|}
\hline \multirow{2}{*}{$\begin{array}{l}\text { Preservation } \\
\text { Period (hr) }\end{array}$} & \multicolumn{3}{|c|}{ Individual sperm motility $\%$} & \multicolumn{4}{c|}{ Live sperm \% } \\
\cline { 2 - 7 } & $\begin{array}{l}\text { Citrate } \\
\text { diluent }\end{array}$ & Tri diluent & $\begin{array}{l}\text { Skim milk } \\
\text { diluent }\end{array}$ & $\begin{array}{l}\text { Citrate } \\
\text { diluent }\end{array}$ & Tri diluent & $\begin{array}{l}\text { Skim milk } \\
\text { diluent }\end{array}$ \\
\hline 0 & 88.56 & 90.17 & 91.50 & 86.30 & 87.65 & 88.10 \\
& $\pm 1.753 \mathrm{Ca}$ & $\pm 2.075 \mathrm{Ba}$ & $\pm 4.187 \mathrm{Aa}$ & $\pm 3.221 \mathrm{Ba}$ & $\pm 2.600 \mathrm{Aa}$ & $\pm 3.339 \mathrm{Aa}$ \\
\hline 48 & 69.25 & 74.50 & 73.60 & 70.40 & 74.50 & 74.61 \\
& $\pm 1.319 \mathrm{Cb}$ & $\pm 3.690 \mathrm{Ab}$ & $\pm 4.464 \mathrm{Bb}$ & $\pm 2.389 \mathrm{Bb}$ & $\pm 2.941 \mathrm{Ab}$ & $\pm 3.935 \mathrm{Ab}$ \\
\hline 96 & 44.82 & 52.21 & 46.50 & 50.00 & 55.50 & 50.27 \\
& $\pm 5.920 \mathrm{Cc}$ & $\pm 3.515 \mathrm{Ac}$ & $\pm 2.691 \mathrm{Be}$ & $\pm 3.279 \mathrm{Bc}$ & $\pm 4.176 \mathrm{Ac}$ & $\pm 2.871 \mathrm{Bc}$ \\
\hline
\end{tabular}

(ABC) capital letters compare between columns while (abc) small letters compare between rows.

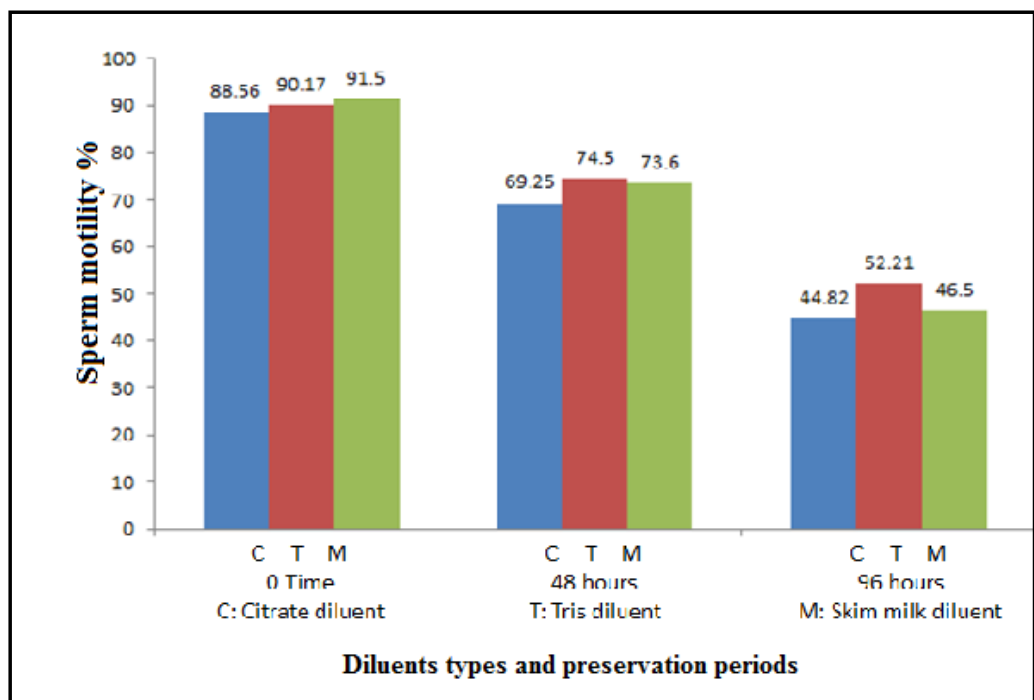

Fig. (1). Effect of diluents types and preservation periods on sperm motility \%

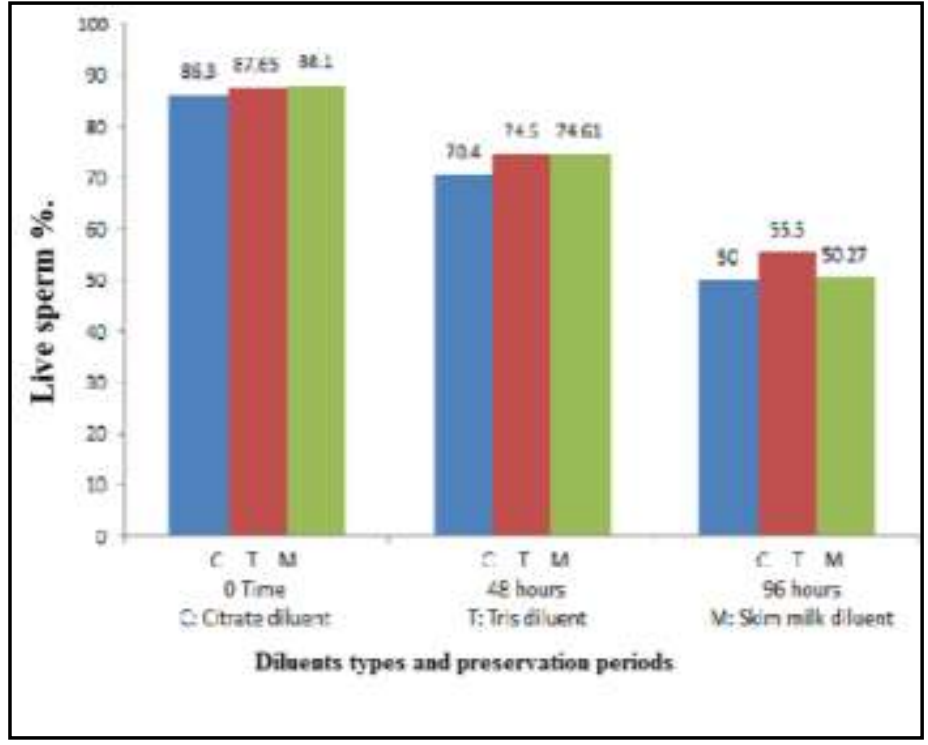

Fig. (2). Effect of diluents types on live sperm \%. 
Salah M. Alragubi

Results of Table (4) and Figures (3\& 4) indicated highly significant differences $(\mathrm{p}<0.01)$ among diluents for abnormal sperm $(\%)$ and $\mathrm{pH}$ of semen. Tris diluents were less significant $(\mathrm{p}<0.01)$ with respect to sperms abnormality in diluted semen than citrate and skim milk dilutions. The abnormal sperms percent increases while $\mathrm{pH}$ decreases with tris diluents when preserving the sperms compared to the other two investigated diluents at different preserving periods. These results are in agreement with those reported by Azawi et $a l .^{(14)}$, Shamsudden and Chanda ${ }^{(15)}$, and Gundigan ${ }^{(8)}$.

Table (4). Effect of diluents type and preservation periods on Abnormal sperm ( \%) and $\mathrm{pH}$ of semen.

\begin{tabular}{|c|c|c|c|c|c|c|}
\hline \multirow{2}{*}{$\begin{array}{l}\text { Preservation } \\
\text { Period (hr) }\end{array}$} & \multicolumn{3}{|c|}{ Abnormal sperm ( \%) } & \multicolumn{3}{|c|}{ PH of semen ( \%) } \\
\hline & $\begin{array}{l}\text { Citrate } \\
\text { diluent }\end{array}$ & Tri diluent & $\begin{array}{l}\text { Skim milk } \\
\text { diluent }\end{array}$ & $\begin{array}{l}\text { Citrate } \\
\text { diluent }\end{array}$ & Tri diluent & $\begin{array}{ll}\begin{array}{l}\text { Skim } \\
\text { diluent }\end{array} & \text { milk }\end{array}$ \\
\hline 0 & $\begin{array}{l}\text { Ac } \\
11.00 \\
\pm 0.707\end{array}$ & $\begin{array}{l}\text { Bc } \\
10.60 \\
\pm 1.025\end{array}$ & $\begin{array}{l}\text { Cc } \\
9.40 \\
\pm 0.899\end{array}$ & $\begin{array}{l}\mathrm{Ba} \\
6.70 \\
\pm 0.324\end{array}$ & $\begin{array}{l}\text { Aa } \\
6.75 \\
\pm 0.315\end{array}$ & $\begin{array}{l}\mathrm{B} \mathrm{a} \\
6.70 \\
\pm 0.342\end{array}$ \\
\hline 48 & $\begin{array}{l}\mathrm{Ab} \\
12.00 \\
\pm 1.340\end{array}$ & $\begin{array}{l}\mathrm{Bb} \\
11.20 \\
\pm 1.069\end{array}$ & $\begin{array}{l}\mathrm{Cb} \\
10.02 \\
\pm 2.561\end{array}$ & $\begin{array}{l}\mathrm{Ab} \\
6.50 \\
\pm 0.300\end{array}$ & $\begin{array}{l}\mathrm{Ab} \\
6.56 \\
\pm 0.317\end{array}$ & $\begin{array}{l}\mathrm{Ab} \\
6.47 \\
\pm 0.349\end{array}$ \\
\hline 96 & $\begin{array}{l}\mathrm{Aa} \\
15.03 \\
\pm 2.588\end{array}$ & $\begin{array}{l}\mathrm{Ca} \\
13.00 \\
\pm 1.719\end{array}$ & $\begin{array}{l}\mathrm{Bc} \\
13.68 \\
\pm 2.325\end{array}$ & $\begin{array}{l}\mathrm{Bc} \\
6.25 \\
\pm 0.361\end{array}$ & $\begin{array}{l}\text { Ac } \\
6.33 \\
\pm 0.249\end{array}$ & $\begin{array}{l}\mathrm{Bc} \\
6.28 \\
\pm 0.286\end{array}$ \\
\hline
\end{tabular}

)AB.C) Capital letters compare between columns while (a.b.c) small letters compare between Rows.

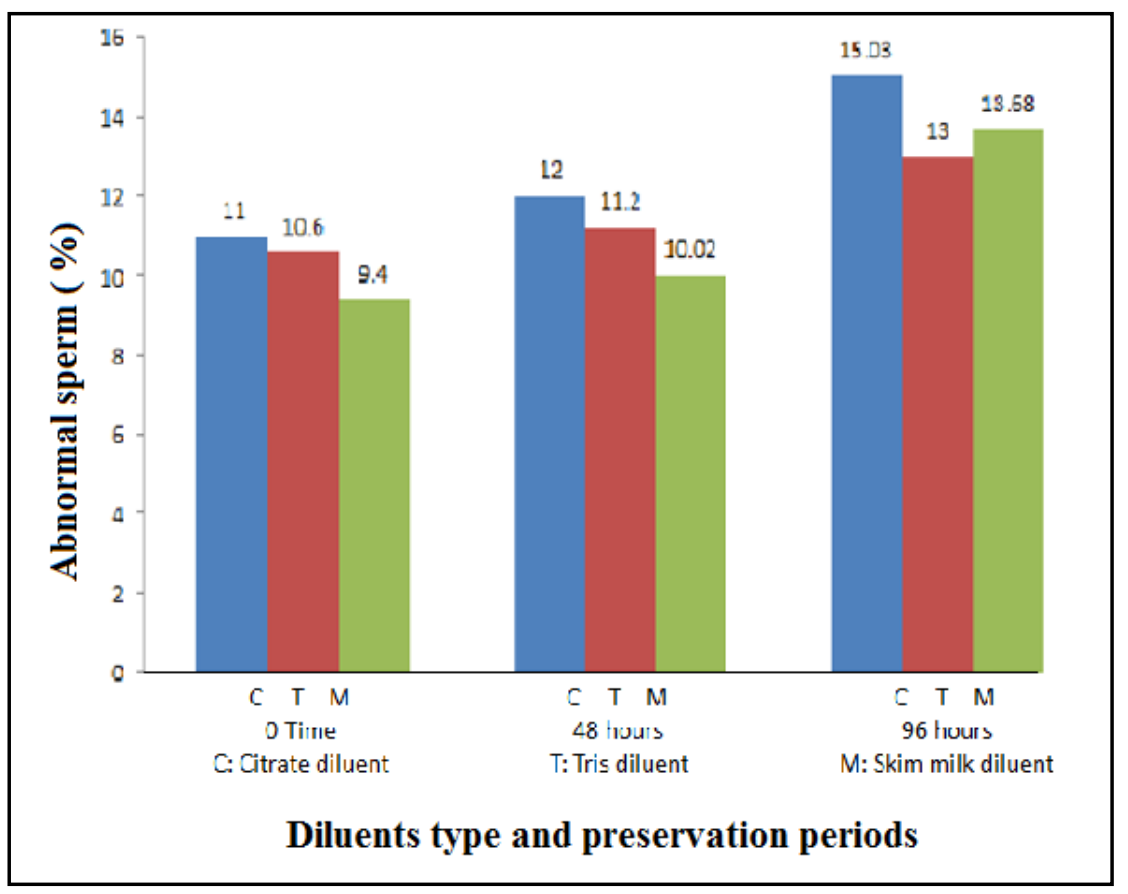

Fig. (3). Effect of diluents type and preservation periods on Abnormal sperm (\%). 


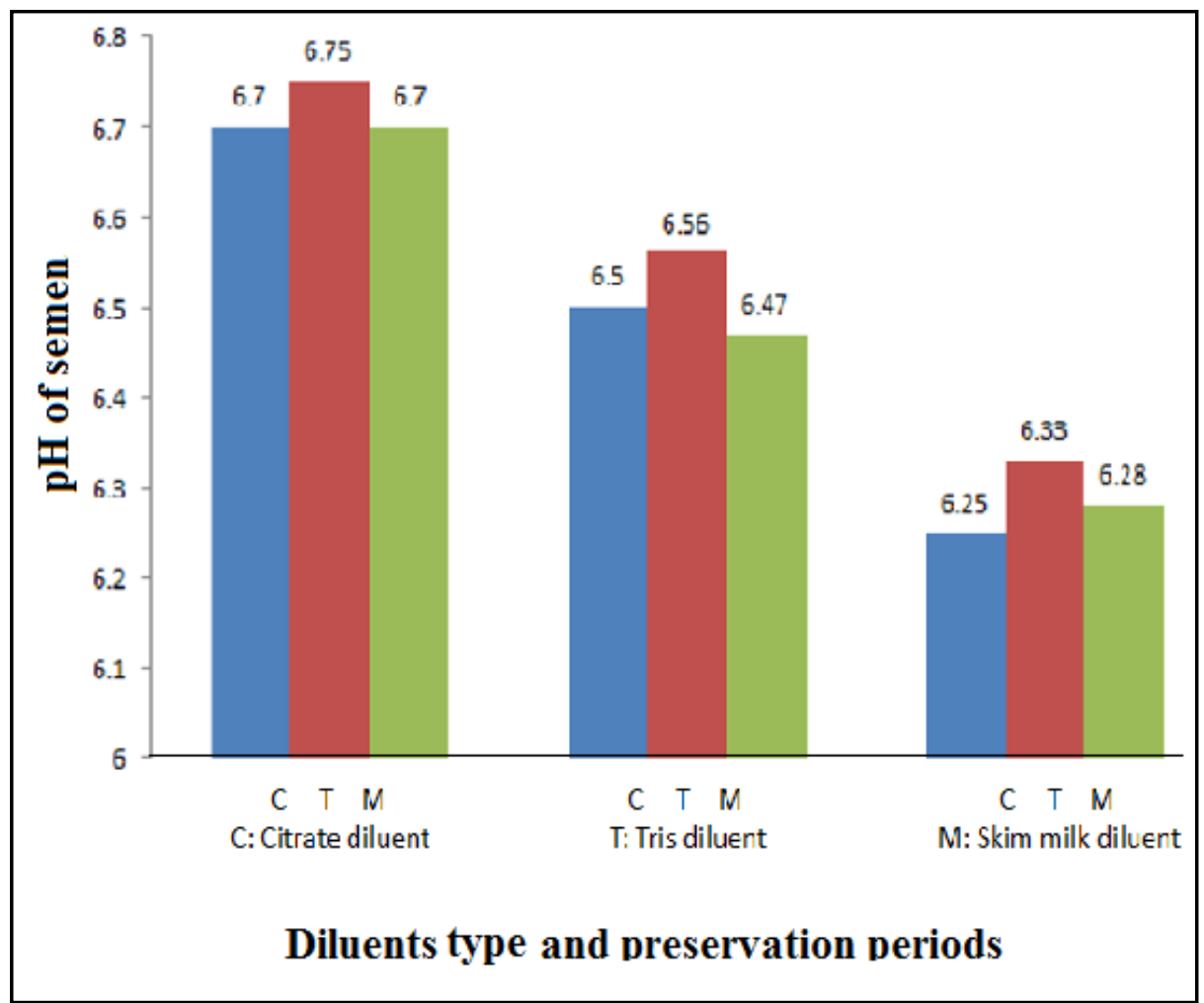

Fig, (4). Effect of diluents type and preservation periods on $\mathrm{pH}$ of semen.

\section{REFERENCES}

1- Lopez, S.; A.N.Ortiz; L. Gallgego and J.J. Gadre (2000). liquid storage $5^{\circ} \mathrm{C}$ of ram semen in different diluents. Arch. Androl., 44:155-164.

2- Kulaksiz, R.; C. Cigdem and E. Akcay (2012). The effect of different extenders on the motility and morphology of ram sperm frozen or stored at $4^{\circ} \mathrm{C}$. Turk J. Vet. Anim. Sci., 36(1) :1103-1111.

3- Chemineau, D.; Y. Cogine; Y. Guerin; P. Orgeure and J.C. Valtet (1991). Training manual on Artificial insemination in sheep and goat. FAO Animal Productive and Health, 3:83-90.

4- Verberckmoes, S.; A. Van Soom; J. Dewulf and Aart de Kruif (2005). Comparison of three diluents for the storage of fresh bovine semen. Theriogenology,63:912-922.

5- Wells, M.E. and O.A. Awa (1970). New technique for assessing acrosomal characteristics of spermatozoa. J. Dairy Sci., 58:227-232.

6- Snedecor, G.W. and W.G. Cochran (1980). Statistical Methods $7^{\text {th }}$ Ed allied pacific, Bombay.

7- Duncan, D.B.K (1995). Multiple range and multiple F test. Biochemistries,11:1-42.

8- Gundigan, M. (2009). Sshort term preservation of ram semen with different extenders. Kafks Univ. Vet. Fac. Derg., 15: 429-435.

9- Salamon, S. and W.M.C . Maxwell (2000). Storage of ram semen. Anim. Reprod. Sci., 62:77-111.

10- Blackshaw, A.W. (1960). The effect of milk diluents on livability rams spermatozoa and their revival after freezing. Aust. Vet., 36:432-435.

11- Deka, B.B. and A.R. Rao (1980a). Preservation of ram semen. Ind. Vet. J., 57:130-134.

12- Deka, B.B. and A.R. Rao (1980b). Effect of extenders on the biometrics of ram sperm head. Ind. Vet. J., 57:905-908. 
Salah M. Alragubi

13- Yaniz, J.L.; P. Santolaria; M.A. Marco-Aguado and F. Lopez-Gatius (2008). Use of image analysis to assess the plasma membrane integrity of ram spermatozoa in different diluents. Theriogenology, 7 .

14- Azawi, O.I.; S.Y.A. AI-Dahash and F.T. Juma (1993). Effect of different diluents on Shami goat semen. Small Ruminant Res., 9:347-352.

15- Shamsudden M.M. and P.K.Chanda (1998). Effect of diluents and dilution rates on the preserved buck semen $4^{\text {th }}$ ASI symposium on Animal Biotechnology (Kanina, Japan) Oct. 7-9.

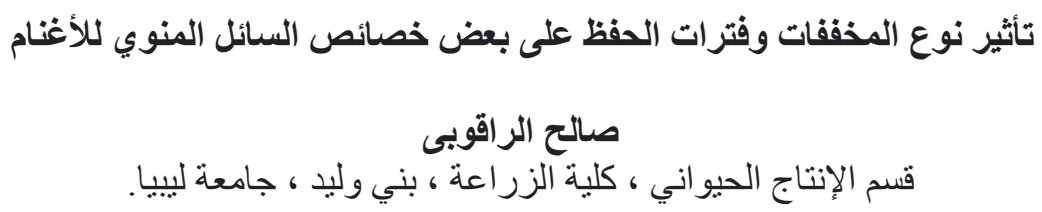

Salehalragobi@gemail.com

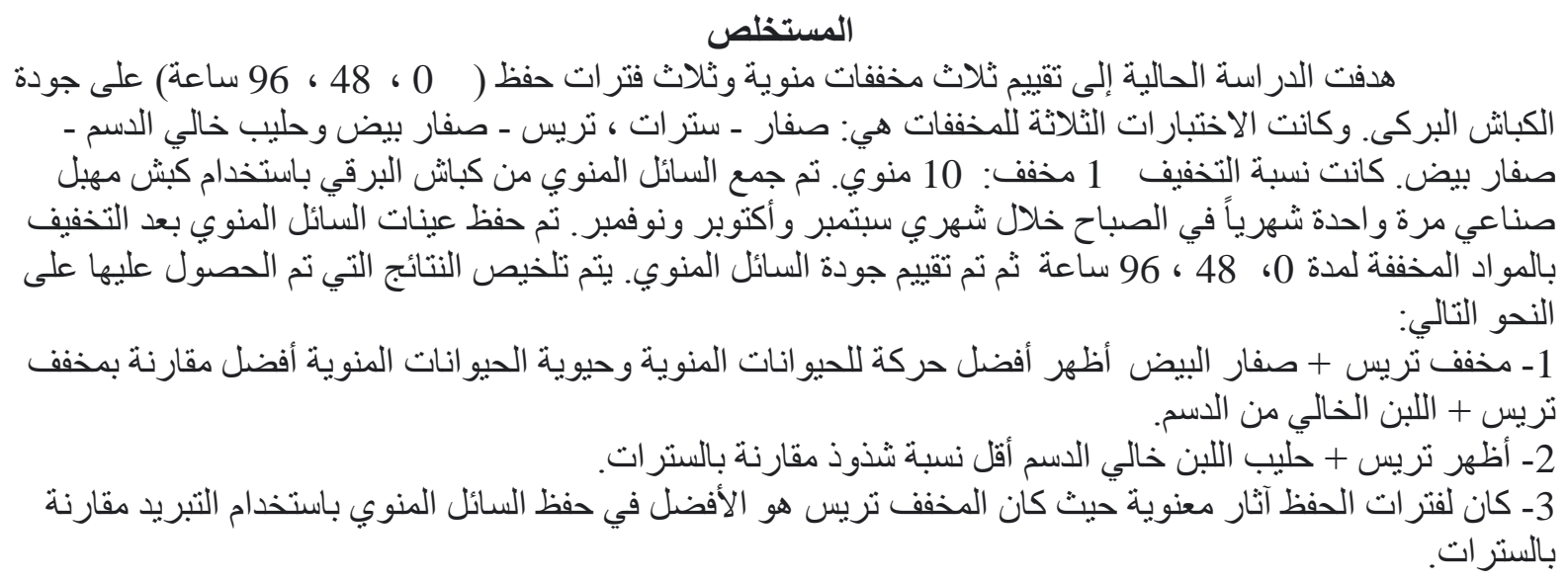

